\title{
Characterization of biominerals in species of Canna (Cannaceae)
}

\author{
Enrique J. Baran ${ }^{1}$, Ana C. González-Baró ${ }^{1}$, María M. Ciciarelli ${ }^{2}$ \& Cristina H. Rolleri ${ }^{2}$ \\ 1. Centro de Química Inorgánica (CEQUINOR, CONICET/UNLP), Facultad de Ciencias Exactas, Universidad Nacional \\ de La Plata, 1900 La Plata, Argentina; baran@quimica.unlp.edu.ar, agb@quimica.unlp.edu.ar \\ 2. Laboratorio de Estudios de Anatomía Vegetal Evolutiva y Sistemática (LEAVES), Facultad de Ciencias Naturales y \\ Museo de La Plata, 1900 La Plata,Argentina; mmciciar@yahoo.com.ar, tinar@speedy.com.ar
}

\author{
Received 05-XI-2009. Corrected 11-V-2010. Accepted 10-VI-2010.
}

\begin{abstract}
Plant biominerals are not always well characterized, although this information is important for plant physiology and can be useful for taxonomic purposes. In this work, fresh plant material of seven wild neotropical species of genus Canna, C. ascendens, C. coccinea, C. indica, C. glauca, C. plurituberosa, C. variegatifolia and C. fuchsina sp. ined., taken from different habitats, were studied to characterize the biominerals in their internal tissues. For the first time, samples from primary and secondary veins of leaves were investigated by means of infrared spectroscopy, complemented with X-ray powder diffractometry and scanning electron microscopy. The spectroscopic results, supported by X-ray powder diffractometry, suggest that the calcium oxalate is present in the form of whewellite $\left(\mathrm{CaC}_{2} \mathrm{O}_{4} \times \mathrm{H}_{2} \mathrm{O}\right)$ in all the investigated samples. It is interesting to emphasize that all IR spectra obtained were strongly similar in all species studied, thus indicating an identical chemical composition in terms of the biominerals found. In this sense, the results suggest that the species of Canna show similar ability to produce biogenic silica and produce an identical type of calcium oxalate within their tissues. These results can be an additional trait to support the relationship among the families of Zingiberales. Rev. Biol. Trop. 58 (4): 1507-1515. Epub 2010 December 01.
\end{abstract}

Keywords: Canna, Cannaceae, biominerals, infrared spectroscopy, X-ray powder diffractometry, opal, biogenic silica, calcium oxalate, whewellite.

The family Cannaceae Juss. belongs to the order Zingiberales, together with other families like Costaceae (K. Schum.) Nak., Heliconiaceae (Endl.) Nak., Lowiaceae Ridley; Marantaceae O. Petersen; Strelitiziaceae (K. Schum.) Hutch.; Musaceae Juss. and Zingiberaceae M. Adanson.

The order is considered monophyletic (Tomlinson 1962, 1969, Dahlgren \& Rassmusen 1983, Kress 1990, Chase et al. 1993, Smith et al. 1993, Kress 1995, Stevenson \& Loconte 1995, Kress et al. 2001) and the Cannaceae, Costaceae, Marantaceae and Zingiberaceae families would represent a unique clade, based on characters such as reduction of androecia to an only functional stamen, large and conspicuous staminodia, seeds with perisperm, absence of raphides in parenchymatic tissues and entire, firm and not torn leaves (Judd et al. 2002).

The genus Canna L. is native of tropical America, although species of Canna are widespread in tropical and subtropical areas all over the world. In America wild species grow in the South of the United States, Mesoamerica and South America, from Venezuela to Argentina. The plants have been cultivated as ornamentals, because of their showy flowers, often large and intensely colored and also many horticultural varieties and hybrids were obtained. Some species naturalized after being introduced in Europe, Asia, Africa and Australia.

Tanaka (2001) has estimated the existence of 19 wild taxa of the genus. Ciciarelli (1995, 2007, Ciciarelli \& Rolleri 2008, Ciciarelli et 
al. 2009) described other three species. Further studies are needed to expand the knowledge of the genus, the number of taxa included and the natural hybrids.

Plants of Canna are rhizomatous terrestrial or palustrine herbs that grow in dense colonies which individuals can reach up to $4 \mathrm{~m}$ height. Terrestrial plants usually live in tropical and subtropical rain forests, montane, premontane and gallery forests. Palustrine plants grow in forest edges, wetlands, marshes and riversides. Many taxa are nitrophilous and mostly found in humic loose soils, near streams, in uncultivated public lands or on road sides. Leaves have large laminae, up to $60 \mathrm{~cm}$ long, with a central well-developed primary vein, also referred to as foliar axis (Solereder \& Meyer 1930). Transversal sections of this vein show external parenchymatic tissues with numerous vascular bundles, and central aerenchyma with diaphragms.

Solereder \& Meyer (1930), Tomlinson (1961, 1962, 1969) and Ciciarelli (1986) have described the morphology of the foliar axis and blades in species of Canna and their work contains so far the unique available information on the presence of biominerals in foliar cells. Using the phenol test (Johansen 1940), Ciciarelli $(1986,1987,1989)$ reported the presence of amorphous silica in hypodermal cells and tissues surrounding secondary veins of $C$. coccinea Mill. and $C$. glauca L. In the same study, the author detected calcium oxalate crystals, using the cupric acetate/ferric sulfate test (Johansen 1940). Calcium oxalate appears as crystalline sand in the epidermal cells, as large crystals or as amorphous aggregates in the cells of the hypodermis and as prismatic crystals in stellate cells of the diaphragms. Prychid \& Rudall (1999) reported oxalate crystals for the Zingiberales, but they did not analyze their composition; later Prychid et al. (2004) found silica in the form of opal.

In the present work we have investigated the existence, characteristics and chemical nature of the biominerals present in the leaves of seven neotropical species of Canna growing in several different habitats, using infrared spectroscopy and complemented with X-ray powder diffractometry.

Species under study were $C$. ascendens Ciciarelli, C. coccinea, C. indica L., C. glauca, C. plurituberosa Tanaka, C. variegatifolia Ciciarelli and C. fuchsina Ciciarelli sp. ined. (Ciciarelli et al. 2009). With the exception of C. glauca, a palustrine or amphibious plant that commonly grows in wetlands and $C$. plurituberosa, a montane species only known from the Jujuy province (Argentina), where it grows up to $1800 \mathrm{~m}$ altitude, the remaining species are widespread terrestrial mesophytes. Canna fuchsina grows in wild, dense colonies, in humid riverside forests from Buenos Aires and Santa Fe provinces, Argentina.

\section{MATERIALS AND METHODS}

Plant material: Studies were performed with fresh plant material collected before this study by one of the authors (MMC). All the samples were collected during February 2009, a month in which plants are flowering, at the following locations in Argentina: a) Province Buenos Aires, City Bell: way Centenario and Lacroze $(C$. ascendens), Rodriguez creek $(C$. indica), way Pellegrini (C. fuchsina); Province Buenos Aires, Ensenada: way to Santiago Island (C. coccinea), La Balandra (C. glauca); c) Province Jujuy: way to Terma de Reyes (1750m) (C. plurituberosa); Province Santa Fe: Road 11, near to Santa Fe City (C. variegatifolia). Three or four leaves of the middle part of each plant were collected and carefully washed with abundant distilled water to remove any possible external contamination. Then, primary and secondary veins were removed to be treated and analyzed. Part of the material was dried and deposited in the Herbarium of the Museo de La Plata.

Several transversal sections of laminae and foliar axes were hand-made to localize biominerals within internal tissues (parenchyma surrounding vascular strands, or in stellate cells of the diaphragms that traverse parenchyma of leaf). Sections were observed with light and/or scanning electronic microscopes. 
Treatment of plant material: The fresh plant samples were treated as follows before its spectra were recorded: a) dry material was pulverized in a vibrating mill (ball mill Retsch, model MM-200) during different periods of time, up to 5 hours, using agate sample holders and balls; b) the milled material or the manually dispersed dry material, was heated in a muffle furnace in air, at different temperatures, up to $400^{\circ} \mathrm{C}$, as suggested by Lanning et al. (1958). Additionally, one sample of each of the investigated plants was treated with diluted (2M) $\mathrm{HCl}$ after heating and the obtained residues were washed several times with distilled water and finally dried at $100^{\circ} \mathrm{C}$.

Infrared spectra: The spectra were recorded on a FTIR-Bruker-EQUINOX-55 spectrophotometer in the range between 4000 and $400 / \mathrm{cm}$, using the $\mathrm{KBr}$ pellet technique (ca. $4 \mathrm{mg}$ of the powdered sample dispersed in $100 \mathrm{mg}$ of $\mathrm{KBr}$ ).

X-ray diffractometry: X-ray powder diagrams were obtained with a Philips PW 1710 diffractometer using monochromatic (Ni-filtered) $\mathrm{Cu}-\mathrm{K}_{\alpha}$ radiation $(\lambda=1.5425 \AA)$.

Scanning electron microscopy: SEM analyses were carried out on fresh plant material using a Jeol-JSMT-100 scanning electron microscope, at the Servicio de Microscopía Electrónica de la Facultad de Ciencias Naturales y Museo de La Plata, Argentina. Transversal sections of the foliar axis and secondary veins were mounted on glass stubs and coated with $\mathrm{Au} / \mathrm{Pd}$ in the usual way. The analyses were carried out using an acceleration voltage of $15 \mathrm{kV}$.

\section{RESULTS}

Infrared spectra: Infrared spectroscopy is a powerful tool for the investigation of plant material (Baran 2005) and we have successfully applied this methodology in the investigation of biominerals of vegetal origin (Monje \& Baran 1996, 1997, 2002a, 2004, 2005, Baran
\& Rolleri 2010). Besides, it is interesting to remark that this is the first time that this methodology is used to the investigation of wild species of genus Canna.

The first interesting result to be emphasized is the fact that in all cases the IR spectra obtained with the milled material of the foliar axis and the secondary veins were strongly similar: this indicates an identical chemical composition in terms of the biominerals found. Thus, the spectra of all the samples resulted comparable and only minor differences in band intensities and position were observed. Since the spectra are identical for the seven taxa, the results can be described and exemplified with any of them. However, there are some references to particular species in appropriate cases.

The IR spectrum recorded with the milled material of the foliar axis of a $C$. ascendens sample is shown in Fig. 1. The intense band located at $1623 / \mathrm{cm}$ is characteristic of calcium oxalate and is assigned to the antisymmetric oxalate $\mathrm{COO}^{-}$stretching mode (Monje \& Baran 1996, 1997). The corresponding symmetric stretching vibration is surely responsible of the medium intensity band found at $1319 / \mathrm{cm}$. The other very strong band, centered at $1042 / \mathrm{cm}$ is one of the characteristic opal bands (Kamatani 1971, Perry 1989). The remaining broad feature located between 800 and $450 / \mathrm{cm}$ includes both oxalate and opal unresolved bands. In

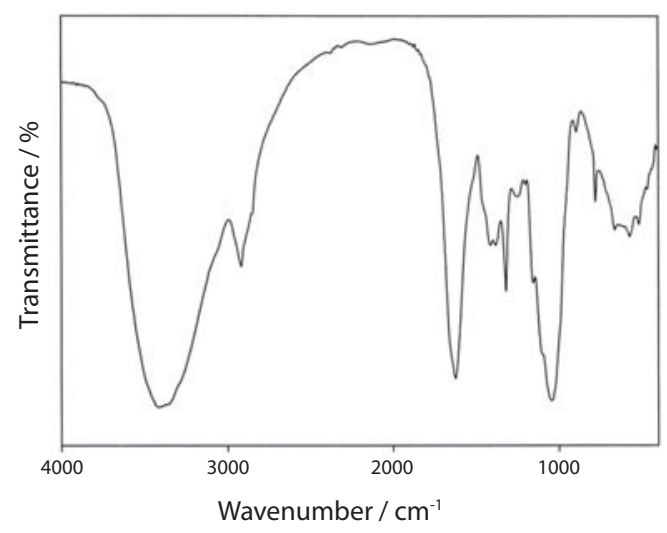

Fig. 1. FTIR spectrum of a milled sample of a foliar axis of $C$. ascendens. 
the higher frequency side of the spectrum, a very strong and broad band, centered at about $3415 / \mathrm{cm}$ with a shoulder at about $3360 / \mathrm{cm}$, is observed. This band is related to $\mathrm{O}-\mathrm{H}$ stretching modes of water and of $\mathrm{Si}-\mathrm{OH}$ groups. Although the second, medium intensity band, centered at $2920 / \mathrm{cm}$ cannot be confidently assigned, it was observed in all the measured samples.

Crystalline calcium oxalates have been found in two different hydration states in plants, either as the monohydrate (whewellite, $\mathrm{CaC}_{2} \mathrm{O}_{4} \times \mathrm{H}_{2} \mathrm{O}$ ) or as the dihydrate (weddellite, $\mathrm{CaC}_{2} \mathrm{O}_{4} \times 2 \mathrm{H}_{2} \mathrm{O}$ ) (Arnott 1982, Monje \& Baran 2002b, Franceschi \& Nakata 2005, Baran \& Monje 2008). It should be noted that it is rather difficult to establish the chemical nature of the calcium oxalate found in these plants. On the basis of the only relatively well defined oxalate IR band (located at $1623 / \mathrm{cm}$ in the $C$. ascendens sample, Fig. 1) one could tentatively suggest the presence of whewellite since in pure whewellite this band is found at $1622 / \mathrm{cm}$ whereas in weddellite it occurs at somewhat higher energies (Babić-Ivančić et al. 1986, Monje \& Baran, 1996, 1997). Interestingly, on the other hand, all of the measured spectra show a well-defined peak located at about $780 / \mathrm{cm}$ (cf. Fig. 1) which seems to be characteristic of the whewellite spectrum. Another fact to mention is that both, the high frequency and the low frequency ranges, which usually allow a clear differentiation between the two forms of calcium oxalate (Monje \& Baran 2002a), appear strongly overlapped by typical $\mathrm{SiO}_{2}$ bands and are highly undefined.

A clearly different IR spectrum is obtained if one of the milled samples or a dry sample of the plant material are slowly heated in a muffle furnace up to $400^{\circ} \mathrm{C}$ and then maintained for 2-3 hours at this temperature. As an example, the spectrum obtained with a sample of $C$. coccinea is shown in Fig. 2. This spectrum reveals the presence of calcite showing bands at $1467 / \mathrm{cm}$ (with a weak shoulder at $1430 / \mathrm{cm}$ ) (antisymmetric stretching, $v_{3}$ ), 871/cm (out of plane deformation, $v_{2}$ ), and $708 / \mathrm{cm}$ (in plane deformation, $v_{4}$ ) (Ross 1972) and the presence

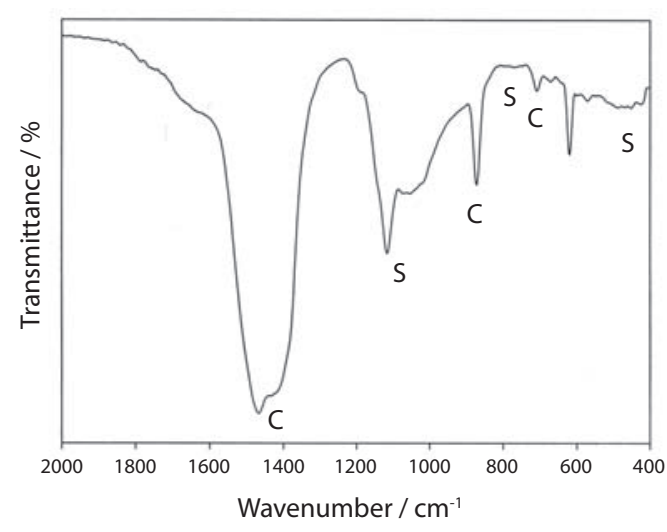

Fig. 2. FTIR spectrum of a milled sample of secondary veins of $C$. coccinea, heated during $2 \mathrm{~h}$ at $400^{\circ} \mathrm{C}$. C $=$ calcite bands; $\mathrm{S}=\mathrm{SiO}_{2}$ (opal) bands.

of opal bands at 1100-1060, 780 and 455/cm (Kamatani 1971, Perry 1989).

X-ray diffractometry: In order to obtain additional and independent information on the chemical nature of the biominerals we have attempted to record X-ray powder diagrams. In most cases, no clear signals could be obtained showing that the materials were highly amorphous. Usually only a broad and undefined feature in the $2 \theta$-range between 20 and $30^{\circ}$ was observed, which is characteristic of the diffraction pattern of biogenic opals (Kamatani 1971, Monje \& Baran 2004). Notwithstanding, in samples (primary and secondary veins) of C. variegatifolia and $C$. fuchsina together with this feature it was possible to observe the three strongest diffraction peaks of whewellite, those with d-values of 5.93, 5.79 and 3.65 (JCPDS PDF file 20-0231), respectively. This finding reinforces the conclusion of the spectroscopic analysis, suggesting that calcium oxalate is present in these plants in the form of the monohydrate.

Scanning electron microscopy: Fig. 3 shows scanning electron microscopy (SEM) images found in foliar tissues of Canna species. In some taxa, such as $C$. coccinea (Fig. 3 

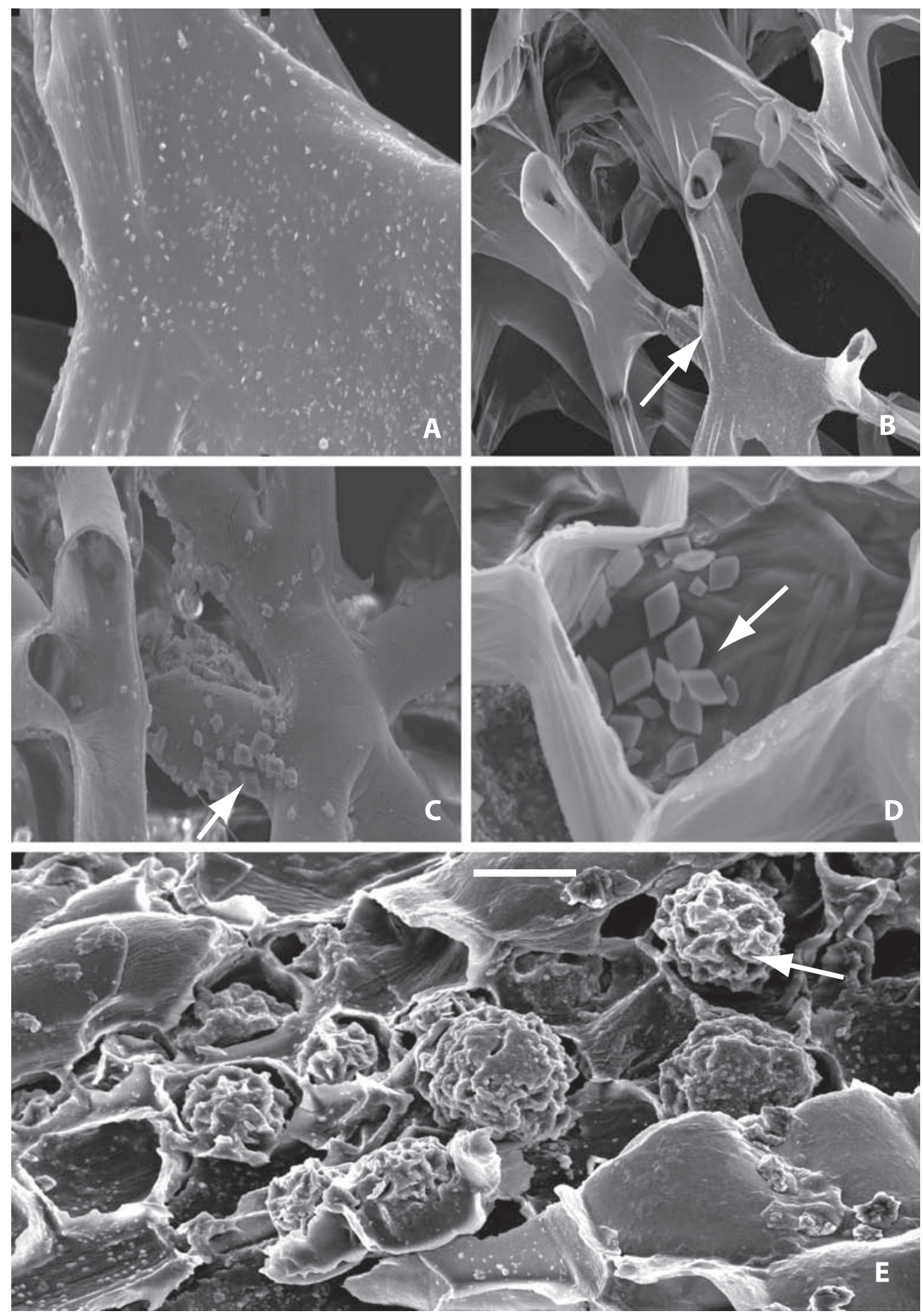

Fig. 3. Biominerals in the foliar tissues of Canna species. A,B: C. coccinea. A: Cells of a diaphragm in foliar axis. B: detail of crystals in A. C: C. ascendens, stellate cell in a diaphragm with crystals. D: C. glauca, large pinacoid crystals in cells near vascular strand of leaf. E: C. ascendens, amorphous opal bodies within internal tissues of foliar axes. Bar=50 $\mu \mathrm{m}$ in A, $100 \mu \mathrm{m}$ in $\mathrm{B}, \mathrm{C}, 10 \mu \mathrm{m}$ in $\mathrm{D}, \mathrm{E}$. 
A,B), the cells of diaphragm of the foliar axes bear small but dense calcium oxalate deposits, while in the stellate cells of diaphragms of $C$. ascendens (Fig $3 \mathrm{C}$ ), as well as in the cells near vascular strands in $C$. glauca (Fig. 3 D) large pinacoid crystals occur. The shape of the calcium oxalate crystals seen in Fig. 3 C,D (rhomboid-shaped [100] pinacoids) is characteristic of whewellite (Hartl et al. 2007), confirming additionally the presence of the monohydrate. In $C$. ascendens, amorphous opal bodies are clearly evident within the internal tissues of foliar axes (Fig. $3 \mathrm{E}$ ).

\section{DISCUSSION}

The performed spectroscopic studies supported by some X-ray powder diffraction measurements as well as by the obtained scanning electron microscopy images, definitively confirm the presence of calcium oxalate in the form of whewellite, in all the investigated samples. The presence of this biomineral is additionally supported by the chemical behavior of the investigated material. The heating of a calcium oxalate/opal mixture generates calcite, whereas opal remains unchanged, as was spectroscopically observed and may be due to the following reaction:

$$
\begin{gathered}
\mathrm{CaC}_{2} \mathrm{O}_{4} \cdot \mathrm{H}_{2} \mathrm{O}+\mathrm{SiO}_{2} \cdot \mathrm{nH}_{2} \mathrm{O} \rightarrow \\
\mathrm{CaCO}_{3}+\mathrm{CO}+(\mathrm{n}+1) \mathrm{H}_{2} \mathrm{O}+\mathrm{SiO}_{2}
\end{gathered}
$$

The subsequent treatment of the obtained solid residue with $\mathrm{HCl}$, decomposes the generated carbonate:

$$
\begin{gathered}
\mathrm{CaCO}_{3}+\mathrm{SiO}_{2}+2 \mathrm{HCl} \rightarrow \\
\mathrm{SiO}_{2}+\mathrm{CaCl}_{2}+\mathrm{CO}_{2}+\mathrm{H}_{2} \mathrm{O}
\end{gathered}
$$

And after washing, $\mathrm{CaCl}_{2}$ is removed and only $\mathrm{SiO}_{2}$ is recovered, as confirmed by the IR spectra which show only the three characteristic absorptions of biogenic silica, together with a weak unidentified feature at $945 / \mathrm{cm}$. This spectrum is identical to those measured in other biogenic silica samples (Kamatani 1971).
Assuming that the number of wild species of the genus can be as high as 19-21 (Tanaka 2001, Ciciarelli \& Rolleri 2008, Delin \& Kress 2009), the number of species studied here represents one third of known taxa included in Canna, thus considered to be representative of what might happen in the genus as a whole.

As was mentioned previously, the Cannaceae shared the presence of biominerals (opal and calcium oxalate) with other six families, such as Costaceae, Heliconiaceae, Lowiaceae, Marantaceae, Strelitiziaceae, Musaceae and Zingiberaceae (Solereder \& Meyer 1930, Tomlinson 1961, 1962, 1969, Ciciarelli 1986). Although no studies like this have been done in other families of the order, the present one suggests that the character, once more investigated in relation to the nature of biominerals present in other Zingiberales, would additionally unify the families of this order and help to support the proposal that this is a monophyletic group.

The study of the biomineralization process in wild plants is still not very advanced, since most works relay on the study of crops, no natural vegetation and no studies like the one performed here are made on the Cannaceae and related families.

Interesting and intriguing aspects of plant biomineralization which remain to be clarified are the reason why plants accumulate these biominerals and their possible functions (Monje \& Baran 2002b, Nakata 2003, Baran \& Monje 2008). In the case of calcium oxalates, the diversity of crystal shapes and sizes, as well as their prevalence and spatial distribution, have led to a number of hypothesis on this aspect, including calcium homeostasis mechanisms, tissue support, plant protection, detoxification and even, light gathering and reflection. On the other hand, the reason why all plants are not highly silicified remains intriguing considering the abundance of silicon dioxide in soils, the high solubility of monosilicic acid in water and the relatively large volumes of water drawn up into the plant body and then lost by transpiration (Monje \& Baran 2002b). Regarding the possible functions of these biogenic silica deposits in the plant kingdom a variety 
of proposals and speculations exist in the literature, including strengthening and stiffening of vegetal structure, decreasing susceptibility to pathogens, detoxification (especially against aluminum and manganese) and improvement of photosynthetic capability (Epstein 1994, Monje \& Baran 2002b).

\section{ACKNOWLEDGMENTS}

This work has been supported by Consejo Nacional de Investigaciones Científicas y Técnicas de la República Argentina (CONICET) and Universidad Nacional de La Plata. The authors are members of the Research Career of CONICET.

\section{RESUMEN}

Los biominerales de las plantas no siempre han sido bien caracterizados aunque esta información es importante en fisiología vegetal y puede ser de utilidad para fines taxonómicos. En este trabajo se estudió material vegetal fresco de siete especies silvestres neotropicales: Canna, C. ascendens, C. coccinea, C. indica, C. glauca, C. plurituberosa, C. variegatifolia and C. fuchsina sp. ined., provenientes de diferentes localidades, con el fin de caracterizar los biominerales presentes en sus tejidos foliares internos. Por vez primera, muestras de venas primarias (ejes foliares) y secundarias de hojas de estas especies se investigaron por medio de espectroscopia de infarrojo, complementada con estudios por difracción de rayos $\mathrm{X}$ de polvos y microscopía electrónica de barrido. Los resultados indicaron la presencia de ópalo (sílice biogénica) y oxalato de calcio en los tejidos vegetales analizados. Además, se determinó que el oxalato de calcio está presente en forma de whewellita $\left(\mathrm{CaC}_{2} \mathrm{O}_{4} \times \mathrm{H}_{2} \mathrm{O}\right)$, información nueva para el género. Tanto el ópalo como la whewellita están presentes en todas las especies analizadas, que representan aproximadamente un tercio de las especies silvestres del género. La capacidad de biomineralizar $\mathrm{SiO}_{2}$ en forma de ópalo en especies de Canna de diversos ambientes resulta también un rasgo altamente sugerente para futuros estudios.

Palabras clave: Canna, Cannaceae, biominerales, espectroscopía de infrarrojo, difractometría de rayos X, ópalo, sílice biogénica, oxalato de calcio, whewellita.

\section{REFERENCES}

Arnott, H.J. 1982. Three systems of biomineralization in plants with comments on the associated organic matrix, p. 199-218. In G.H. Nancollas (ed.). Biological Mineralization and Demineralization. Springer, Berlin, Germany.

Babić-Ivančić, V., H. Füredi-Milhofer, B. Purgarić, N. Brničević \& Z. Despotović. 1986. Precipitation of calcium oxalates from high ionic strength solutions. III. The Influence of reactant concentration on the properties of the precipitates. J. Cryst. Growth 71: 655-663.

Baran, E.J. 2005. Applications of vibrational spectroscopy to the investigation of plant material, p. 365-392. In H. Hemantaranjan (ed.). Advances in Plant Physiology Vol. 8. Scientific, Jodhpur, India.

Baran, E.J. \& P.V. Monje. 2008. Oxalate biominerals, p. 219-254. In A. Sigel, H. Sigel \& R.K.O. Sigel (eds.). Metal Ions in Life Sciences, 4. Wiley, Chichester, England.

Baran, E.J. \& C.H. Rolleri. 2010. IR-spectroscopic characterization of biominerals in the marattiaceaeus ferns. Rev. Bras. Bot., in press.

Chase, M.W., D.E. Soltis, R.G. Olmstead, D. Morgan, D.H. Les, D. Mishler, M.R. Duvall, L.R. Price, H.G. Hills, Y. Qui, A. Kyron, J.H. Retting, E. Conti, J.D. Palmer, J.R. Manhart, K.J. Sytsma, H.J. Michaels, W.J. Kress, K.G. Karol, W.D. Clark, M. Hedren, B.S. Gaut, R.K. Jansen, K. Kim, C.F. Wimpee , J.F. Smith, G.R. Furnier, S.H. Strauss, Q. Xiang, G.M. Plunkett, P.S. Soltis, S.E. Swensen, S.E. Williams, P.A. Gadek, C.J. Quinn, L.E. Eguiarte, E. Golenberg, G.H. Learn Jr., S. Graham, C.H. Barrett, S. Dayanandan \& V.A. Albert. 1993. Phylogenetics of the seed plants: an analysis of nucleotide sequences from the plastid gene rbcL. Ann. Miss. Bot. Garden 80: 528-580.

Ciciarelli, M.M. 1986. Aportes al conocimiento histoquímica del mesófilo en especies de Canna L (Cannaceae). Notas Mus. La Plata, Bot. 21: 13-22.

Ciciarelli, M.M. 1987. Aplicación del concepto de arquitectura foliar a la sistemática de especies de Canna $\mathrm{L}$ (Cannaceae) de la ribera del Plata. Notas Mus. de La Plata, Bot. 21: 87-97.

Ciciarelli, M.M. 1989. Las Cannaceae Link argentinas. Tesis Doctoral, Facultad de Ciencias Naturales y Museo de La Plata, La Plata, Argentina.

Ciciarelli, M.M. 1995. Canna variegatifolia Ciciarelli (Cannaceae-Zingiberales), una nueva especie para Argentina. Rev. Museo La Plata, Bot. 14: 333-341.

Ciciarelli, M.M. 2007. Canna ascendens Ciciarelli (Cannaceae) una nueva especie de la provincia de Buenos 
Aires y comentarios sobre otras especies argentinas de este género. Dawiniana 45: 187-209.

Ciciarelli, M.M. \& C.H. Rolleri. 2008. Morfología, taxonomía y caracterización de siete especies neotropicales del género Canna (Cannaceae, Zingiberales). Botánica Complutensis 32: 157-184.

Ciciarelli, M.M., C.H. Rolleri \& M.C. González Dubox. 2009. Canna fuchsina, una especie nueva para la ciencia, sus relaciones con otras especies silvestres del género y con el grupo C. $x$ generalis (CannaceaeZingiberales). Botanica Complutensis, in press.

Dahlgren, R.M. \& F.N. Rassmusen. 1983. Monocotyledon evolution: characters and phylogenetic estimation. Evol. Biol. 16: 187-209.

Delin, W. \& W.J. Kress. 2009. Cannaceae. In The Flora of China 24: 378. Science (Beijing) and Missouri Botanical Garden, St. Louis, Missouri, USA.

Epstein, E. 1994. The anomaly of silicon in plant biology. Proc. Natl. Acad. Sci. U.S.A. 91: 11-17.

Franceschi, V.R. \& P.A. Nakata. 2005. Calcium oxalate in plants: formation and function. Annu. Rev. Plant Biol. 56: 41-71.

Hartl, W.P., H. Klapper, B. Barbier, H.J. Ensikat, R. Dronskowski, P. Müller, G. Ostendorp, A. Tye, R. Bauer \& W. Barthlott. 2007. Diversity of calcium oxalate crystals in Cactaceae. Canad. J. Bot. 85: 501-517.

Johansen, D.A. 1940. Plant Microtechnique. McGraw Hill, New York, USA.

Judd, W.S., C.S. Campbell, E.A. Kellog, P.F. Stevens \& M. Donoghue. 2002. Plant Systematics. A Phylogenetic Approach. Sinauer Assoc., Sunderland, Massachusetts, USA.

Kamatani, A. 1971. Physical and chemical characteristics of biogenous silica. Mar. Biol. 8: 89-95.

Kress, W.J. 1990. The phylogeny and classification of Zingiberales. Ann. Missouri. Bot. Garden 77: 698-721.

Kress, W.J. 1995. Phylogeny of the Zingiberaceae: Morphology and molecules, p. 443-460. In P.J. Rudall, P.J. Cribb, D.J. Cuttler \& C.J. Humphries (eds.). Monocotyledons: Systematics and Evolution. Royal Botanical Gardens, London, England.
Kress, W.J., L.M. Prince, W.J. Hahn \& E.A. Zimmer. 2001. Unraveling the evolutionary radiation of the families of the Zingiberales using morphological and molecular evidence. System. Biol. 50: 926-944.

Lanning, F.C., B.W.X. Ponnaya \& F.C. Crumpton. 1958. The chemical nature of silica in plants. Plant Physiol. 33: 339-343.

Monje, P.V. \& E.J. Baran. 1996. On the formation of weddellite in Chamaecereus silvestrii, a cactaceae from northern Argentina. Z. Naturforsch. 51c: 426428 .

Monje, P.V. \& E.J. Baran.1997. On the formation of whewellite in the cactaceae species Opuntia microdasys. Z. Naturforsch. 52c: 267-269.

Monje, P.V. \& E.J. Baran. 2002a. Characterization of calcium oxalates generated as biominerals in cacti. Plant Physiol. 128: 707-713.

Monje, P.V. \& E.J. Baran. 2002b. Plant biomineralization, p. 395-410. In H. Hemantaranjan (ed.). Advances in Plant Physiology Vol. 7. Scientific, Jodhpur, India.

Monje, P.V. \& E.J. Baran. 2004. Complex biomineralization pattern in cactaceae. J. Plant Physiol. 161: 121-123.

Monje, P.V. \& E.J. Baran. 2005. Evidence of formation of glushinskite as a biomineral in a cactaceae species. Phytochemistry 66: 611-614.

Nakata, P.A. 2003. Advances in our understanding of calcium oxalate crystal formation and function in plants. Plant Sci. 164: 901-909.

Perry, C.C. 1989. Chemical studies of biogenic silica, p. 223-256. In S. Mann, J. Webb \& R.J.P. Williams (eds.). Biomineralization. Chemical and Biochemical Perspectives, Chemie, Weinheim, Germany.

Prychid, C.J. \& P.J. Rudall. 1999. Calcium oxalate crystals in monocotyledons: A review of their structure and systematics. Ann. Bot. 84: 725-739.

Prychid, C.J., P.J. Rudall \& M. Gregory. 2004. Systematics and biology of silica bodies in monocotyledons. Bot. Rev. 69: 377-440.

Ross, S.D. 1972. Inorganic Infrared and Raman Spectra. McGraw-Hill, London, England. 
Smith, J.F., W.J. Kress \& E.A. Zimmer. 1993. Phylogenetic analysis of the Zingiberales based on rbcL sequences. Ann. Missouri Bot. Garden 80: 50-66.

Solereder, H \& F. Meyer. 1930. Cannaceae, p. 56-62. In Systematische Anatomie der Monokotiledonen, Vol. 6. Gebr. Borntraeger, Berlin, Germany.

Stevenson, D.W. \& H. Loconte. 1995. Cladistic analysis of the monocot families, p. 543-578. In P.J. Rudall, P.J. Cribb, D.J. Cuttler \& C.J. Humphries (eds.). Monocotyledons: Systematics and Evolution. Royal Botanical Gardens, London, England.
Tanaka, N. 2001. Taxonomic revision of the family Cannaceae in the New World and Asia. Makinoa, New Ser. 1: 31-33.

Tomlinson, P.B. 1961. The anatomy of Canna. J. Linnean Soc. London (Botany) 56: 467-473.

Tomlinson, P.B. 1962. Phylogeny of the Scitamineae: morphological and anatomical considerations. Evolution 16: 192-213.

Tomlinson, P.B. 1969. Commelinales-Zingiberales, p.295421. In C.R. Metcalfe (ed.). Anatomy of the Monocotyledons. Clarendon, Oxford, England. 